\title{
AGAINST ALL ODDS: ALPHAEUS ZULU AND RACISM IN CHURCH AND SOCIETY
}

\author{
R Simangaliso Kumalo \\ University of KwaZulu-Natal \\ kumalor@ukzn.ac.za \\ Henry Mbaya \\ University of Stellenbosch \\ hmbaya@sun.ac.za
}

\section{ABSTRACT}

This article examines the response of Bishop Alphaeus Hamilton Zulu to the racism that was prevalent in both the church and society when he was elected as the first African Bishop of the Anglican Church in South Africa. Clergy, especially bishops, are by virtue of their ecclesial positions expected to transcend racial prejudices, to embrace all members of their churches and to transform their churches to multi-racial ones. This means that they have to deal with racial stereotypes both within the church and society at large. This study is based on interviews with key leaders of the Anglican Church who knew and worked with Bishop Zulu, as well as an analysis of media releases and minutes of meetings that he was part of and some that were written about him. This article argues that Bishop Zulu played a pivotal role in the fight against racism, through his episcopal ministry which brought politics and religion into a creative tension, when he worked as bishop, speaker of the Legislative Assembly in Natal and key founder of the Inkatha Freedom Party (IFP). It also argues that church leaders must hold politics and religion together for their ministry to bring transformation to both the church and society.

Keywords: Anglican; blacks; apartheid; racism; whites; Christian; church; segregation

\section{UNISA}

Studia Historiae Ecclesiasticae Volume 41 | Number 2 | 2015 pp. 4-17
DOI: http://dx.doi.org/10.17159/2412-4265/2015/152 Print ISSN 1017-0499 | Online 2412-4265 (C) 2015. Studia Historiae Ecclesiasticae 


\section{INTRODUCTION}

In this paper we outline the life and ministry of Bishop Alphaeus Hamilton Zulu from 1905 to $1988^{1}$ as a priest, bishop, an ecumenical leader, as well as his political role. In particular, it traces his life history to KwaZulu; his involvement in the wider South African community as a member of the African National Congress (ANC), the Inkatha Freedom Party (IFP), and as an international ecumenical leader. The paper particularly focuses on his struggles against apartheid, which also involved the social welfare projects which he initiated to alleviate poverty. It will illustrate how his life seemed to have impacted the lives of others struggling against apartheid. This study seeks to respond to two interrelated critical questions: What contribution did Bishop Zulu make to the church and society in South Africa? What factors possibly influenced his contribution?

\section{Some theoretical considerations}

The life history and ministry of Bishop Zulu falls within the category of a phenomenon, commonly called the missionary indigenisation of the clergy in Southern Africa. In his work, The making of an indigenous clergy in Southern Africa, Denis $(2007,25)$ draws attention to the insufficient record, mostly by white missionaries, of the life stories and ministries of the African clergy in Southern Africa, an omission which contributed to disproportionate missionary historiography. ${ }^{2}$ In some way, this study is an attempt to fill the gap. It is an attempt to document the unravelled history of the indigenous clergy. This study seeks to record a history of Bishop Zulu, mainly drawing from archival documents and other secondary literature.

\section{Bishop Zulu: Background on his life and work}

Alphaeus Hamilton Zulu was born on 29 June 1905 to Johannes and Miriam Kilo Zulu in Nqutu, KwaZulu. He belongs to the Zulu royal dynasty. His father was a policeman as well as a farmer. After his elementary education at Hlazakazi (19121916) and Magogo (1916-1918) in Nqutu, he attended Newcastle Intermediate School (1918-1919), went to train as a teacher at Milton School, Alcockspruit, and received his teaching qualification from St. Chad's Training College, Ladysmith (Lukhele 2015, 3). He became the principal of Umlazi Intermediate School in 1926 (Lukhele 2015, 3). He also studied privately and obtained his Junior Certificate in

1 South African History Online. http://www.sahistory.org.za/people/bishop-alphaeushamilton-zulu (accessed 26 March 2015).

2 See P. Denis, 2007. The making of an indigenous clergy in Southern Africa: Proceedings of the International Conference, held at the University of Natal, Pietermaritzburg 25-27, October 1994: Cluster Publications. 
1931. That same year, he became the principal of Umlazi Combined School. He also continued his private study during this period and obtained his matriculation certificate in 1935 (Lukhele 2015, 3). Zulu was accepted into the University of Fort Hare in Alice where he obtained his Bachelor of Arts degree in Social Anthropology (1936-1938). Having experienced ${ }^{3}$ what he saw as a calling from God, Zulu joined St. Peter's Theological College, Johannesburg in 1939, where he obtained a Licentiate in Theology (Deane 1978, 240).

Deane observed that Zulu was driven to the religious life neither by the contemplative life nor 'the theological esoteric', but rather by 'the possibilities for uplifting people' (Deane 1978, 205). It would seem that his concern and love for people and a deep desire to uplift their social and economic welfare remained a key feature of his entire work in the church and society. In 1940, he was ordained a deacon and sent to St. Faith's Mission, Durban as a curate in 1941 (Lukhele 2015, 3). He took over as the priest in charge of St. Faith's in 1952. He was elected suffragan bishop of St. John's Diocese, Umtata, in 1960 (Clarke 2008, 207). In this position, Bishop Zulu was subordinate to the diocesan bishop, which in fact meant that he had very little power. In spite of the constitutional change that the Anglican Church had introduced to the position of suffragan bishop, Zulu did not see any substantive change to his position. In 1964, he confided to the Rev. James Calata, writing that:

According to the Constitution and Canons of the Church of the Province of South Africa, the change of name to Suffragan from Assistant Bishop makes no difference at all to my position and responsibilities (or lack of them). Nothing therefore has happened to help me to see light or hope where I am...I quite definitely do not see myself serving in this situation after next year...I continue now to ask for the support of your prayers because my one desire is to do what God approves. (Zulu in Goedhals 1989,121)

Two years after expressing this frustration, he was elevated to the position of Diocesan Bishop of the Anglican Bishop of Zululand and Swaziland respectively in 1966 and in 1968, the Bishop of Zululand. When Zulu was consecrated as bishop, he became part of a long tradition of African pioneer clergy reaching back to Titus Mthembu (Pascoe 1901, 341), the first black priest to be ordained in the Diocese of Zululand in ACSA in 1894; Peter Masiza, the first black Anglican priest in ACSA in 1870 (Goedhals 1989, 23); and even Tiyo Soga of the Presbyterian Church, the first black clergyman in South Africa in 1864 (Attwell 1995, 23). Zulu's elevation to the order and office of a bishop was beyond the imagination of many, given the apartheid laws and the persistent racism in Christian institutions, including the Anglican Church at that time. This gave rise to questions about his suitability as bishop over both white and blacks in such an environment. Bishop Zulu's response to some of these questions was:

3 Also see the South African History Online. http://www.sahistory.org.za/people/bishop-alphaeushamilton-zulu (accessed 20 October 2014). 
No man can know he is the right person for any position. And I imagined that even if I should be suitable I might not be chosen because I am an African. So you see, my election has helped my faith tremendously for I believe that it can only have been through the guidance of a higher hand. I have always believed that there are people in South Africa who want to do things as God would have them done, this is evidence of it. It is a challenge to us who believe in Christ wherever we may find ourselves and in whatever work we may be engaged for him, the church or society. (Umtata. Group from Disp. ELD. 1190/2809. 30/09/1966. PC 165/4)

Bishop Zulu was not only a priest but a leader who was deeply involved in the life of the society through his work and membership of many associations. He held different leadership positions in the Interdenominational African Ministers' Association of South Africa (Idamasa); he was on the executive committees of the Christian Council of South Africa, Natal Teachers' Association, and African Enterprise (Deane 1978, 204). He co-founded the Natal Bantu Cane Growers' Association in 1934 with Albert Luthuli. He was a member of the South African Institute of Race Relations. He joined the African National Congress, but after his retirement as Bishop of Zululand in 1975, left the ANC and joined the Central and National Committees of the Inkatha yeNkululeko yeSizwe, where he served as its first National Chairperson, 1975-1976 (Lukhele 2015, 11). He was also a member of the KwaZulu Legislative Council and served as speaker (South African History Online. http://www.sahistory. org.za/people/bishop-alphaeus-hamilton-zulu). In his tribute to Bishop Zulu, Chief Buthelezi noted that Zulu and President Kaunda of Zambia were partly responsible for his founding of the Inkatha Freedom Party, as they had each independently suggested the founding of a uniting body for the people that would help focus the struggle of South Africans at that time. ${ }^{4}$

Bishop Zulu's unique personality and qualities appeared to have attracted much praise. The former Archbishop of Cape Town, the Rt. Reverend Bill B. Burnett, said of Bishop Zulu that 'he had a remarkable gift of wisdom, a warm and sensitive spirit and a joyful sense of humour, a godly political pragmatist...I do not think I have known a man with greater gifts of wisdom' (Burnett 1988, PC 165/2). Chief Buthelezi, who was a close friend and associate of Bishop Zulu, described him as a man blessed with deep humility and deep faith. He asserted: 'As Priest, counsellor and friend, Bishop Zulu had a bottomless pit of wisdom. As a man, he had unbounded love.' His life was about serving his people and all human beings. This service, according to Buthelezi, gained him respect across all political camps, such that 'even his political enemies loved him' (Buthelezi 1988, PC 165/8). Others described Bishop Zulu as a man who possessed great intellect, charm, a humble and dignified man, these as his 'most valuable attributes' (Umtata, ELD. 1190/2809. 30/09/1966, PC 165/4). A parishioner recounts the great love and acceptance of Bishop Zulu by parishioners during his time at St. Faith's because of his concern for his people, his

4 M.G. Buthelezi. 1988. 'Tribute to Bishop Alphaeus Hamilton Zulu' (Allan Paton Centre - PC 165/8), 6 . 
leadership qualities, and the ways in which he stood for and protected his members (Burnett 1988, PC 165/5).

\section{The struggle of Bishop Zulu with racism within and outside the church}

Bishop Zulu lived and worked in a time when racial segregation was continually being institutionalised and its negative effect on the black population of South Africa was heightening. It was also a time when many churches, despite the racial segregation within them, tried to condemn it, at least in the public sphere. The Anglican Church, together with other churches under the umbrella of the South African Council of Churches (SACC) was known to be critical of racial segregation. This was particularly so in the 1970s and onwards when black people became more involved in church leadership and the leadership of ecumenical councils like the SACC. Many of these black leaders were said to be extremely vocal in expressing their opposition to racism in the country (Bosch 1979, 13). In spite of the fact that many of the white religious leaders and members of the SACC, including the Anglican Church, considered themselves to be against racial segregation, being also the official position of their churches, however, the realities at grassroots level showed that racism was still a major problem among ordinary members (Bosch 1979, 13).

Bishop Zulu's recounting of some of his own experiences of racism points to the kind of difficulty that blacks had to go through within and outside their church, irrespective of their social or religious standing. It also points to the difficulty of achieving and maintaining the ideals of equality pursued by church leaders - even by proponents of such ideals within the Anglican Church. He says:

I could dilate endlessly upon my own personal experiences and the humiliations I have suffered as an individual person on account of my colour. I refer to it all because every black man has experienced it and hated it. Nearly every class of white person has had his share in treating me as less than man - missionaries and bishops of my own Church; ordinary white men of the working class assaulted me for failing to call them Boss, or the garage foreman who abandoned me to my fate because I could not tell him in Afrikaans what the trouble was with my car; the group of professors who in utter disregard for his status as political leader of black South Africa sent the late Chief Luthuli and me to drink tea in a little cell that served them for a kitchen; or the State President who turned down my appeal for temporary asylum in a bishop's house situated in a white town while I built mine in a black town. (Zulu 1972, $8-9)$

During his episcopate, Bishop Zulu faced many racial challenges. It seems that the government of the day perceived him as a potential threat. His house and offices were raided and searched twice (PC 165) (Muhammad 2011, 205). In 1971 he was also arrested for not carrying a passbook, which the laws of that time compelled every black person to carry around. In the same year his passport was confiscated a 
number of times; once when he was to travel for a global meeting of the Anglican communion in England, and again when he was to travel to Geneva for a World Council of Churches (WCC) meeting, fearing that he would reveal to the world the gross inhumanity perpetrated by the apartheid regime (Muhammad 2011, 205). The South African government would delay, refuse or confiscate travel documents of people who stood against their policies and were considered as threats to the apartheid state (Muhammad 2011, 205).

The 1970s was an era when black theology and black consciousness were impacting some communities in South Africa. Writing to Bishop Zulu on 29 November 1971, Archbishop Selby Taylor alerted him that in a meeting in Cape Town some 'Heads of Churches', government ministers and particularly the Minister of Internal Affairs had been troubled for what they saw as his role in allowing the development of 'Black Theology' in Zululand. In response to the Archbishop's letter, Bishop Zulu stated:

I am not surprised that the attitude of the authorities should be as you report. I have suspected all along that this should be the case. I believe, however, that we have a duty to perform here if our young people especially will not be lost to the Church. I am satisfied that we should be involved in the changes that are taking place in an effort to direct them all towards our Lord. (AB 1285 Historical Papers, William Cullen Library, Witwatersrand University)

The Archbishop's intimation to Bishop Zulu would suggest that he, Zulu, could have been under security surveillance by the apartheid government. On his election as bishop, Zulu was forbidden from moving into the official bishop's residence in Eshowe because it was in a white area. This was because of the Group Areas Act which organised residences according to race (Mbaya 2012, 270). However, Bishop Zulu, who had hoped that he would be allowed to take his rightful residence, responded to this huge challenge thus: '... where I stay is not my prime consideration, wherever I stay my main concern is my work...the important thing is to stay somewhere in Zululand so that I can do my work' (Daily News. 28/09/1966. PC 165; Natal Mercury, 2 October 1966).

\section{Struggle with racism in the Anglican Church}

Bishop Zulu did not only have to deal with these challenges from the government but as indicated in his words above, from all categories of white people whether outside or within the Anglican Church. Indeed, the racial challenges within the church are only a reflection of the wider society in which the church is situated. Mr John Mkhize, a former church warden at St. Faith's during the rectorship of Bishop Zulu, recalls that when Bishop Zulu first arrived at St. Faith's as a priest in Durban, he was asked to live at the bachelors' quarters and not the rectory because the bachelors' quarters had been built for blacks and the rectory for whites, which at that time was occupied by a Reverend Steel. However, St. Faith's being a black mission, the parish 
council insisted that Bishop Zulu must live in the rectory because he had young children. Their insistence led to the transfer of Rev. Steel to make space for Bishop Zulu, despite Steel's insistence that the rectory was built for white clergy (School of Theology, PC 165/5).

His appointment as Bishop of Zululand brought about some dilemma and confusion among many white Anglicans. Some saw the development as a plausible one and an indication that the Anglican Church was living up to its principles and practising what it preached. However, many whites were deeply shocked. A newspaper reporter narrated the reaction of a white Anglican housewife to the news of the election of Zulu as the first black Bishop of Zululand: 'I know it's silly. I know he is a good chap but I don't like the idea of him confirming my daughter' (Daily News 28/09/1966. PC 165). It is reported that some families actually refused to allow him to lay his hands on their daughters' heads and that some members actually left the church for other churches (South African History Online. http://www.sahistory. org.za/ people/bishop-alphaeus-hamilton-zulu).

It would seem that in spite of these challenges, Bishop Zulu did not harbour any hatred or grudge against whites, nor did the challenges deter him from carrying on with his work and service to the people. It also did not make him lose faith in the Christian religion. His attitude towards this challenge is perhaps best captured in his exhortation to both blacks and whites: '.. get off each other's backs... All of us are in the process of development, of growth, Whites and Blacks both... There can be good or bad in anyone' (Muhammad 2011, 206).

This is not to suggest that Bishop Zulu was indifferent towards white supremacy or that he was insensitive to the harsh reality in which blacks lived within a system that defined and treated them as less human because of their skin colour. It points to the fact that he did not see change as the responsibility of members of one race only, but as something that both races must take responsibility for. But also, he strongly felt that black people need to be more self-reliant. 'When the black opens his eyes, when he stands on his feet, when he thinks for himself - and this takes education, it takes the Christian religion, it takes economic freedom - the races will relate to each other in their equal humanity' (Muhammad 2011, 206).

This partly reflects Bishop Zulu's general response to racial segregation in the country. But the Bishop spoke consistently about the issue in different places, to different audiences and at different times. This shows his commitment to transformation and exposes us to his thoughts about racism and what needs to be done to bring about change, often speaking from a Christian perspective. It would seem that his experience with white lay people sometimes contrasted with the hierarchy. The bishops of the province would entrust him with some important responsibilities. At the height of apartheid in 1978, during the retreat at St. Paul's College in Grahams Town, Bishop Zulu addressed the students on 'the action of Jesus on the law of love', 'the realization of the action of the Holy Spirit in our ministry'; 'Reconciliation and Jesus the Prince of Peace' (AB 2568 Historical Papers, William Cullen Library, 
Witwatersrand University). On this occasion, one former student, Howard Bradshaw said that he experienced him as a man of wisdom, humility and holiness (Mbaya, Interview with Howard Bradshaw, Pietermaritzburg 20/12/13).

Bishop Zulu believed strongly that poverty and dependence made the situation of black South Africans worse than it should be. Thus, he promoted self-reliance, particularly among blacks. Regarding their Christian life, Bishop Zulu encouraged and guided his church members in a way that allowed them to grow on their own. He encouraged people to be responsible and take control over their lives so that they can create opportunities for self-sustenance and self-employment, which will also allow them to contribute to the church (Mbaya 2012). His concern about the poor situation of South Africans made him to also organise financial help for many students using his connections in and outside South Africa (Burnett 1988, PC 165/2). Bishop Zulu seemed to understand deeply the wounds that apartheid education had inflicted on the intellect of blacks to the extent that it tended to undermine their capacity to engage more meaningfully with their white counterparts. Professor John Suggit recalled that one day Bishop Zulu, then suffragan bishop of St. John's diocese (Mthatha), remarked that as 'the African students studying at St. Bede's College came from a background intellectually different from that of their Europeans counterparts at St. Pauls' it would be unfair to rush them to get to grasp issues of racial unity, rather they be given some time to grapple with these issues' (Mbaya, Interview with Prof. John Suggit, Noordhoek, Cape Town, 22/04/13).

It was also this desire to address poverty and to promote self-sufficiency that led Bishop Zulu and Chief Albert Luthuli to found the Natal Bantu Cane Growers' Association in 1934, which enabled families to start small gardens so that they could become self-sufficient.

\section{A pacifist approach to conflict}

The Bishop also believed that only peaceful means of bringing about change in South Africa should be pursued. From his contact and association with Chief Albert Luthuli, he is said to have been convinced that a peaceful outcome was a possibility, and that change in South Africa could only be achieved through peaceful means. He learned too, from Luthuli's attitude towards whites, that 'when blacks know themselves to be the equals of whites, and act it, whites will behave as equals themselves' (Deane 1978, 205). Thus, Bishop Zulu would not accept any form of violence and promoted passive resistance. This accounted for his controversy with the WCC.

The WCC had voted to withdraw its financial contributions from organisations that were commercially engaged with South Africa, South West Africa and territories in Portuguese Africa in order to put pressure on the oppressive governments in these regions. The WCC also encouraged their members to employ their influence in ensuring that relevant corporations withdraw from trading with these countries. The WCC further made a decision to send contributions from its 'Special Fund to 
Combat Racism' to guerrilla fighters, although the council claimed that this was to be used only for the education and medical requirements of these fighters. As one of the six presidents of the WCC, Bishop Zulu stood against these resolutions, supported by Mr. John Rees, the Secretary General of the South African Council of Churches. Their argument was that encouraging corporations to withdraw and disinvest from South Africa would be to the disadvantage of black South Africans, thus, the WCC should rather encourage the kinds of investments that would help to uplift black South Africans. They also argued that sending funds to guerrilla fighters would imply support for violence. This position gained increasing support among member churches in South Africa, many of which dissociated themselves from the WCC and/or its decision. Bishop Zulu argued that the major duty of the church was to promote reconciliation rather than promote violence (Horrell, Horner, KaneBerman and Margo 1973, 48-49).

Walshe $(1983,14)$ notes that for white churchmen these issues of violence and non-violence were very confusing and emotionally upsetting. Many whites who were in solidarity with blacks and in opposition to apartheid were deeply offended. Walshe (1983) argues that the tense political situation at that time and the dangers that any hint of or conspicuous desire to dialogue with or contact the ANC and PAC attracted, were great. This explains the reaction of church leaders in South Africa to the WCC's resolution. It also helps to see why many white people concluded, instinctively, that the WCC's support for the welfare and publicity of the liberation movements automatically implied support for the use of violence to bring about change in South Africa (Walshe 1983, 115).

Although Bishop Zulu condemned such an approach to change in South Africa, in his T.B. Davie memorial lecture on the dilemma of the black South African in 1972, he raised questions about whether non-violence was still a tenable approach, given the persistence of racial segregation. He said:

Very few whites in this country are committed to non-violence and there is no reason why there should be any more among blacks. After the disillusionment which followed the quelling of black passive resistance movement in the middle fifties, it has become unreasonable to gain support for the hope of a non-violent solution. The harshness with which discrimination is enforced by law and custom makes a black man look simple and naïve if he continues to believe and talk of non-violence ever becoming effective. This is a fact even though nobody speaks of violence. (Zulu 1972, 4)

Bishop Zulu regretted the fact that many blacks were not given the opportunity to contribute to the development of the country due to the many restrictions placed on them, yet violence was not the appropriate solution. He believed that the white population in South Africa would discover at some point that 'all people in the country belong together and will be willing to share the good things it has' (Umtata, ELD 1190-2809, 30/09/1966. PC 165/4). In his response to the question put to him during the retreat at St. Paul's College in 1974 by Howard Bradshaw as to how 
apartheid could be dismantled, Bishop Zulu is said to have answered 'go and pray about it' (Mbaya, Interview with Howard Bradshaw, Pietermaritzburg, 12/03/14).

According to Bishop Zulu, the church must play its role in this by inspiring, leading and encouraging members to 'live in fellowship with God and one another'. He warned that for the intellectual African, Christianity could become less appealing. Because whites found it especially difficult to practise this fellowship with Africans, teaching the ideals of love as a core of the Christian faith had become increasingly difficult. However, the African must not expect more Christian perfection from whites than from him/herself, because he would be disappointed by the inability of the whites to live up to the ideal of Christianity. ${ }^{5}$ Some white people held him in very high esteem. In 1974, when the Anglican Church was considering to elect the Archbishop of Cape Town, one white person, Rev. Tim F.D. Bravington, wrote to him asking him if he could allow his name to be put forward. Part of his letter stated:

May I have your permission to propose you for election as the next Archbishop of Cape Town? We do not know each other personally so I imagine you would like to know why I wish to propose you. One reason is personal. When I was married, in London just over three years ago, my Best man was the Rev. Anthony Salmon. He always spoke very highly of you. So, too, did a couple whose name I now forget, whom I met on one of the diamond mines in Namaqualand: she had been confirmed by you. I have also read with great interest your recent articles in Pro Veritate. You may protest that you are too old. My answer is that Pope John was also old and look what he did! I also believe that you are a wise man and this is a gift which is enhanced by age. I also feel that we need an Archbishop who is more than just a local figure. Your position in the World Council of Churches has, I believe, given you a world vision of the position of your church and it is this sort of vision which I think we need from our Archbishop. You are South African, if I may use this term widely, and I do not think this is the moment for us to look overseas for a new Archbishop. You are also Black and I think this is important for the church in South Africa today. I am White, English born and trained, South African educated and ordained. (AB 2925 Z 1, Historical Papers, William Cullen Library, Witwatersrand University)

His secretary merely responded that his letter had been received as the bishop was overseas. Bavington's letter showed Bishop Zulu as a man who appealed to people across the colour line. Ivan Weiss, former senior Chaplain to Archbishop Bill Burnett in the 1980s confided to one of the authors that Bishop Zulu would have been a great Archbishop. ${ }^{6}$ In his time as Bishop he was inundated with many requests to conduct retreats or lead other functions, which he sometimes declined due to his busy schedule. Fatima Meer wrote asking him to be one of the patrons of the Antipoverty Programme for Indians and Blacks. The University of Natal awarded Bishop Zulu a doctorate Honoris Causa in 1974 (AB 2925 Z1, Historical Papers, William Cullen Library, Witwatersrand University).

5 'Umtata: An African today.'

6 Interview with Henry Mbaya, Rondebosch, Cape Town, 15/09/14. 
In their campaign for the release of jailed political leaders, the National Union of South African Students (NUSAS) looked to him for moral support. On 10 May 1974, the Chairman of NUSAS, Charles Nupen, wrote to Bishop Zulu. Part of the letter read:

During the past few decades, the African continent has been the scene of vast and sweeping changes...the effects of this call must inevitably reach South Africa...the large majority have for many years called for full participation in the determination of this country's affairs...It is in this context that NUSAS will embark upon a campaign during the final week in May, calling for the release of political prisoners in South Africa. It is logical that such an action must be accompanied by a lifting of repressive political measures which, far from providing a lasting peaceful solution, only serve to increase the potential for eventual violent conflict. It is with a sense of realism and with a deep concern for all the peoples of this sub-continent that we make our call and ask for your support.

In his response Bishop Zulu said:

Thank you for your letter and the copy of the statement released by you on your campaign for the release of the political prisoners. It is not easy to make intelligent comments on these matters but I wish you to know how many of us appreciate the stance which young white people are taking in matters of race relations in this country. It is one of the most hopeful things you young people can be in being so determined to identify with Black folk that we shall in fact become one society and one community. It is difficult to see how South Africa can survive otherwise. We pray that the powers-that-be will hear the Spirit in which you are speaking and make the kind of response which will be helpful for the future in our beloved land. (AB 2529, Z1 Historical Papers, William Cullen Library, Witwatersrand University)

Perhaps due to the fact that some people and organisations looked to Bishop Zulu for moral support and advice, he was drawn closer to participate in what appeared as 'partisan' South African politics.

\section{Bishop Zulu's involvement with the KwaZulu politics}

Bishop Zulu was deeply involved in the governance of KwaZulu. After his retirement as Bishop of Zululand in 1975, he accepted the invitation from Chief Buthelezi to join the central committee of the Inkatha Freedom Party (IFP), the founding of which he had also inspired. He served as its first National President and also as Speaker of the KwaZulu Legislative Assembly.

Bishop Zulu had joined the ANC the same year as Chief Luthuli. However, he left the ANC due to the ban on it by the government, which did not allow the ANC to pursue its objectives peacefully in South Africa. He joined the IFP because of the party's commitment to non-violence as stated in its mission statement (South African History Online. http://www.sahistory.org.za/people/bishop-alphaeus-hamilton-zulu; Mbaya 2012, 'Ungusobaba'). 
The Bishop however, did not consider himself a politician but saw himself as being there to encourage and help Africans to achieve their goals. As Buthelezi noted:

He was a member of the Inkatha central committee and helped to shape it right from its inception...he was never a politician but he was for ever a fount of wisdom amongst politicians. He never aspired to political power and always his wisdom was exercised to make political decisions relevant to the suffering people. He always stated so often that he was not a politician, and yet I am yet to experience such political astuteness which he had in such abundance. (Buthelezi 1988, PC 165/8)

In spite of this assurance, others have tended to criticise Bishop Zulu for what they saw as his 'partisan' politics with the IFP. However, even if he had continued to be a member of the ANC, he would still be identified with 'partisan' politics. We need to note that his joining the IFP and KwaZulu politics seemed to have alienated him from some circles in the church. The problem is that the IFP was an ethnicbased organisation, which went beyond just political partisanship, but here it was interpreted as if he was promoting ethnic-based politics.

\section{CONCLUSION}

In this paper we traced the life of Bishop Zulu, his early life and his rise to leadership positions in church and society. This essay specifically highlighted Bishop Zulu's struggles against apartheid, both in the church and in society. It is a modest attempt to appraise one who brought religion and politics into a creative tension in order to achieve holistic liberation for the people of South Africa. It has brought to our attention the fact that racial discrimination was also experienced deeply by those who were leaders of the church, like Bishop Zulu. Bishop Zulu has been dead for almost three decades now but, when we follow his story, we are confronted by one who pioneered the position of an African Bishop in the Anglican Church of Zululand. He pioneered a number of organisations that enabled liberation and development for the African people - all this in the name of the gospel. South Africans must not only remember him as a pastor but also as a community leader and an ecumenist.

\section{LIST OF REFERENCES}

Attwell, D. 1995. 'The transculturation of Enlightenment: The exemplary case of the Rev. Tiyo Soga, African Nationalist.' In P. Denis (ed.), The making of an indigenous clergy in Southern Africa: Proceedings of the International Conference, held at the University of Natal, Pietermaritzburg 25-27, October 1994: Cluster Publications.

Bosch, D.J. 1979. 'Racism and revolution: Response of the churches in South Africa.' Occasional Bulletin of Missionary Research.

Bradshaw, H. Interview with Henry Mbaya, Pietermaritzburg, 12/03/13.

Burnett, D. 1988. 'Alphaeus Hamilton Zulu (1905-1988).' Natalia 8 PC 165/2. 
Buthelezi, M.G. 1988. 'Tribute to Bishop Alphaeus Hamilton Zulu.' Allan Paton Centre PC 165/8.

Clarke, B. 2008. Anglicans against apartheid. Pietermaritzburg: Cluster Publications.

Daily News. 'Anglican Bishop's office searched.' 25/08/1964. Allan Paton Centre PC 165.

Daily News. 'Bishop's home still no decision.' 28/09/1966. PC 165.

Deane, D.S. 1978. Black South Africans: A who's who: 57 profiles of Natal's leading blacks. Cape Town: Oxford University Press.

Denis, P. 2007. The making of an indigenous clergy in Southern Africa: Proceedings of the International Conference, held at the University of Natal, Pietermaritzburg 25-27, October 1994: Cluster Publications.

Goedhals, M. 1989. 'From paternalism to partnership?' Bounty in Bondage, The Anglican Church in Southern Africa, Johannesburg: Ravan Press.

Horrell, M.D., Horner, J., Kane-Berman and R. Margo. 1973. A survey of race relations in South Africa, 1972. Johannesburg: South African Institute of Race Relations.

Lukhele, M. 2015. Inselelo yoMbhishobhi owaziwayo kubaholi bezombusazwe. INKAZIMULO, uLwesine Apral 02, 3.

Mbaya, H. 2012. 'Ungusobaba [You are our Father]: The life of an Anglican Bishop, Lawrence Bekisisa Zulu.' Bekisisa Zulu (1937-2013+). www.unisa.ac.za.

Muhammad, R. 2011. 'Bishop AH Zulu.' The Natal Mercury, 12 Thursday 2011, 205.

Natal Mercury. The short biography of Bishop AH Zulu. 2 October 1966, p. 8.

PC 107. The John Morrison Collection. Killie Campbell Archives, UKZN.

Pascoe, C.F. 1901. Two hundred years of the SPG: An historical account of the Society of the Propagation of the Gospel in foreign parts, 1701-190. London: SPG.

School of Theology, Oral History Project: The Rectorship of Rev. A.H. Zulu. PC 165/5.

South African History Online. 'Bishop Alphaeus Hamilton Zulu.' http://www.sahistory.org.za/ people/bishop-alphaeus-hamilton-zulu (accessed 20 October 2014).

Suggit, J. Interview with Henry Mbaya, Noordhoek, Cape Town, 22/04/13

Umtata. An African today becomes head of the Anglican Church of whites and blacks in South Africa, making an epoch in the church of the province. Group from Dips ELD 30/09/1966. PC 165/4.

Walshe, P. 1983. Church versus state in South Africa: The case of the Christian Institute. London: C. Hurst \& Co.

Weiss, I. Interview with Henry Mbaya, Rondebosch, Cape Town, 15/09/14.

Zulu, AH. 1972. The dilemma of the black South African. The twelfth T.B. Davie memorial lecture delivered in the University of Cape Town on 17 May, 1972. Cape Town: Standard Press Ltd.

\section{Additional sources consulted}

American Committee on Africa. 1971. 'Bishop Alphaeus A Zulu Visits the US.' ACOA Notes, no. 4.

KCM 98/3/5 Correspondence: religious (General): Letter from the British Council of Churches to the South African Government (8/07/1982). 
Macqueen, I. 2005. 'Piety and praxis: A study of the early life and thought of Bishop Alphaeus Zulu.' BA Honours Thesis, University of KwaZulu-Natal, Historical Studies.

Mufamadi, T.D. 2011. 'The World Council of Churches and its Programme to Combat Racism: The evolution and development of their fight against apartheid, 1969-1994.' Doctoral Thesis, University of South Africa.

'Priest urges change of heart.' (Newspaper report 28/06/1957).

Zulu, A.H. 1951. 'The future of the African.' KCM. 98/3/25. Religious Notebooks. 